\title{
EFFECT OF ASCORBIC ACID ON RHEUMATOID SYNOVIAL FLUID*
}

\author{
BY \\ EMANUEL ABRAMS AND JOHN SANDSON $\dagger$ \\ From the Department of Medicine, Albert Einstein College of Medicine, \\ Bronx Municipal Hospital Center, New York, N.Y.
}

Robertson, Ropes, and Bauer (1939) were the first to show that L-ascorbic acid could cause a marked decrease in the viscosity of solutions of hyaluronate. Ascorbic acid is present in the blood of normal persons in concentration high enough to cause a decrease in the viscosity of solutions of purified hyaluronate. It is not known whether ascorbic acid plays a role in the pathogenesis of diseases in which depolymerization of hyaluronate is thought to occur.

The concentration of ascorbic acid in the synovial fluid of patients with rheumatoid synovitis was determined and correlated with (1) the concentration of ascorbic acid in the serum, and (2) the reduced viscosity of the synovial fluid.

$$
\text { Reduced Viscosity }=\frac{\text { Relative Viscosity }-1}{\text { Hyaluronate (g./per cent.) }}
$$

On two occasions L-ascorbic acid was injected intra-articularly to determine its rate of disappearance from an involved knee joint of a patient with rheumatoid arthritis, and to study the effect in vivo of large concentrations of L-ascorbic acid on the viscosity of the hyaluronate in the synovial fluid.

\section{Methods}

(1) General.-The knee joints of six patients with bilateral or unilateral knee joint effusions were aspirated a total of twelve times. By the criteria of the American Rheumatism Association as revised by Ropes, Bennett, Cobb, Jacox, and Jessar (1959) four patients had classical and two had probable rheumatoid arthritis. A venous blood sample was drawn at the time of joint aspiration. All samples were immediately placed in ice water at $4^{\circ} \mathrm{C}$.

\footnotetext{
* Presented in part at the 9th Interim Meeting American Rheumatism Association, December, 1962, Richmond, Virginia.

+ Investigator, Health Research Council of the City of New York (Contract No. I-157).
}

\section{(2) Preparation of Products}

(a) Hyaluronate.-Purified hyaluronate protein was prepared by the method of Sandson and Hamerman (1962) from normal synovial fluids. The concentration of hyaluronate was determined by the hexuronic acid method of Dische (1947) as modified by Bowness (1957).

(b) Protein Fractions.-Protein fractions of normal serum and of rheumatoid synovial fluid were prepared by zone electrophoresis on a polyvinyl chloride block in barbital buffer $(0 \cdot 075 \mathrm{M}, \mathrm{pH} 8 \cdot 6)$ as described by Kunkel and Trautman (1959). After electrophoresis the block was cut in $\frac{1}{2}$-inch segments and the protein eluted by displacement filtration. The protein content of each eluate was determined by the Folin method modified by Lowry, Rosebrough, Farr, and Randall (1951). The appropriate eluates were pooled and then concentrated by ultrafiltration in a collodion bag. The homogeneity of each fraction was verified by paper electrophoresis at pH 8.6 in barbital buffer $(0.075 \mathrm{M})$.

(3) Synovial Fluid Analyses.-The concentration of ascorbic acid was immediately determined by the method of Roe and Kuether (1943) and Roe (1961). Known amounts of $\mathrm{L}$-ascorbic acid added to synovial fluid could be recovered quantitatively by this method. The hyaluronate concentration was determined by the hexuronic acid method as modified by Decker, McGuckin, McKenzie, and Slocumb (1959). The total white count, differential white count, and total protein were determined. The relative viscosity of the fluid was measured in an Ostwald viscometer (2-ml. capacity) at $25 \pm 0 \cdot 2^{\circ} \mathrm{C}$. after dialysis in phosphate-NaCl buffer $\left(0.04 \mathrm{M} \mathrm{PO}{ }_{4}\right.$; $0 \cdot 10 \mathrm{M} \mathrm{NaCl} ; \mathrm{pH} 7 \cdot 2$ ).

(4) Action of Ascorbic Acid on Whole Rheumatoid Synovial Fluid

(A) $1 \mathrm{ml} .45 \gamma \mathrm{L}$-ascorbic acid per ml. was added to each of three tubes containing

(1) $2 \mathrm{ml}$. whole rheumatoid synovial fluid,

(2) $2 \mathrm{ml}$. purified hyaluronate

(3) $2 \mathrm{ml}$. buffer.

The tubes were incubated at $37^{\circ} \mathrm{C}$. for $18 \mathrm{hrs}$, 
and the relative and reduced viscosities were then determined.

(B) $100 \mathrm{mg}$. L-ascorbic acid was administered intraarticularly to an involved knee joint of two patients with rheumatoid arthritis. The knee was moved passively to ensure mixing, and synovial fluid and serum samples were drawn at designated intervals over a 3 to $3 \frac{1}{2}$ hour period. All samples were kept in an ice bath at $4^{\circ} \mathrm{C}$., and at the end of the experiment the ascorbic acid content and the relative and reduced viscosities of the synovial fluid samples were determined as above.

(5) Inhibition Studies.--Studies were also undertaken to determine which substances in serum or synovial fluid could inhibit the viscosity-reducing effect of $\mathrm{L}$-ascorbic acid on purified hyaluronate. To $1.8 \mathrm{ml} .750 \gamma$ hyaluronate per $\mathrm{ml}$. was added $0.5 \mathrm{ml}$. of either the albumin, alpha $_{1}$, alpha $a_{2}$, beta, or gamma globulin fraction of normal serum. The protein concentration of each fraction was approximately 20 per cent. of the protein concentration of that fraction in the whole serum. To each tube was then added $0.2 \mathrm{ml} .185 \gamma$ per $\mathrm{ml}$. L-ascorbic acid so that the final concentration of L-ascorbic acid was $15 \mathrm{\gamma} / \mathrm{ml}$. The mixtures were incubated at $37^{\circ} \mathrm{C}$. for $18 \mathrm{hrs}$. The relative and reduced viscosities were then determined.

The inhibiting activity of the following was studied in the same manner as above:

(a) protein fractions of rheumatoid synovial fluid;

(b) ultrafiltrate of normal serum;

(c) normal serum before and after dialysis in a phosphate $\mathrm{NaCl}$ buffer $(1,000 \mathrm{~m}$. changed twice in 24 hrs);

(d) dialyzed normal serum plus the ultrafiltrate of normal serum.

\section{Results}

(1) Synovial Fluid Analyses.-The levels of ascorbic acid in synovial fluid and serum are shown in Table I. In nearly every case the ascorbic acid concentration in synovial fluid was approximately the same as the concentration in simultaneously drawn serum.

The relationship of the ascorbic acid concentration in synovial fluid to the reduced viscosity of the fluid is shown in the Figure. Those fluids with low

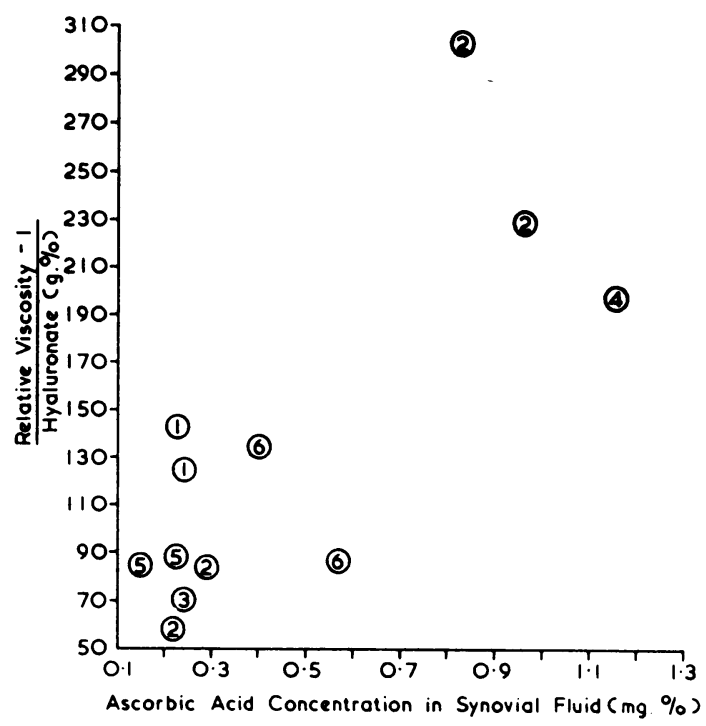

Figure.-Correlation of concentration of ascorbic acid in rheumatoid synovial fluid with the reduced viscosity of the synovial fluid. Reduced Viscosity $=\frac{\text { Relative Viscosity }-1}{\text { Hyaluronate (g./per cent. })}$

TABLE I

LEVELS OF ASCORBIC ACID IN SERUM AND SYNOVIAL FLUID IN 6 CASES

\begin{tabular}{|c|c|c|c|c|c|c|c|c|c|c|}
\hline \multirow[b]{2}{*}{ Case No. } & \multirow[b]{2}{*}{ Diagnosis } & \multirow{2}{*}{$\begin{array}{c}\text { Knee } \\
\text { Aspirated }\end{array}$} & \multicolumn{2}{|c|}{ Ascorbic Acid ( $\gamma / \mathrm{ml}$.) } & \multicolumn{6}{|c|}{ Synovial Fluid } \\
\hline & & & Serum & Fluid & $\mathrm{WBC} / \mathrm{mm}^{3}$ & $\begin{array}{c}\text { Poly- } \\
\text { morphs }\end{array}$ & $\begin{array}{c}\text { Protein } \\
(\mathrm{mg} / \mathrm{ml} .)\end{array}$ & $\begin{array}{l}\text { Relative } \\
\text { Viscosity }\end{array}$ & $\begin{array}{l}\text { Hyaluronate } \\
\text { (g. per cent.) }\end{array}$ & $\begin{array}{l}\text { Reduced } \\
\text { Viscosity }\end{array}$ \\
\hline 1 & Rheumatoid Arthritis & $\begin{array}{l}\mathbf{R} \\
\mathbf{L}\end{array}$ & $\begin{array}{l}2 \cdot 8 \\
2 \cdot 8\end{array}$ & $\begin{array}{l}2 \cdot 4 \\
2 \cdot 3\end{array}$ & $\begin{array}{r}950 \\
23,150\end{array}$ & $\begin{array}{c}15 \\
\text { mostly }\end{array}$ & 二 & $\begin{array}{l}6 \cdot 00 \\
5 \cdot 41\end{array}$ & $\begin{array}{l}.0405 \\
.0309\end{array}$ & $\begin{array}{l}123 \cdot 4 \\
142 \cdot 7\end{array}$ \\
\hline 2 & Rheumatoid Arthritis & $\begin{array}{l}\mathbf{R} \\
\mathbf{L} \\
\mathbf{R} \\
\mathbf{L}\end{array}$ & $\begin{array}{l}8 \cdot 1 \\
7 \cdot 3 \\
2 \cdot 9 \\
2 \cdot 0\end{array}$ & $\begin{array}{l}9 \cdot 7 \\
8 \cdot 4 \\
2 \cdot 9 \\
2 \cdot 2\end{array}$ & $\begin{array}{c}7,500 \\
4,800 \\
-\end{array}$ & $\begin{array}{l}85 \\
65 \\
- \\
-\end{array}$ & $\begin{array}{l}\overline{56 \cdot 8} \\
- \\
-\end{array}$ & $\begin{array}{r}13 \cdot 30 \\
12 \cdot 82 \\
8 \cdot 69 \\
11 \cdot 98\end{array}$ & $\begin{array}{l}.0539 \\
.0391 \\
.0928 \\
.1883\end{array}$ & $\begin{array}{r}228 \cdot 2 \\
302 \cdot 3 \\
82 \cdot 8 \\
58 \cdot 3\end{array}$ \\
\hline 3 & Rheumatoid Arthritis & $\mathbf{L}$ & $1 \cdot 9$ & $2 \cdot 4$ & 37,600 & 80 & $54 \cdot 0$ & $4 \cdot 64$ & $\cdot 0518$ & $70 \cdot 2$ \\
\hline 4 & $\begin{array}{c}\text { Rheumatoid Arthritis } \\
+ \text { Psoriasis }\end{array}$ & $\mathbf{R}$ & $11 \cdot 8$ & $11 \cdot 6$ & 10,300 & 85 & $36 \cdot 6$ & $13 \cdot 55$ & $\cdot 0652$ & $192 \cdot 4$ \\
\hline 5 & $\begin{array}{c}\text { Probable } \\
\text { Rheumatoid Arthritis }\end{array}$ & $\begin{array}{l}\mathbf{R} \\
\mathbf{L}\end{array}$ & $\begin{array}{l}2 \cdot 9 \\
2 \cdot 9\end{array}$ & $\begin{array}{l}2 \cdot 3 \\
1 \cdot 5\end{array}$ & $\begin{array}{l}4,850 \\
6,750\end{array}$ & $\begin{array}{l}90 \\
85\end{array}$ & $\begin{array}{l}38 \cdot 1 \\
37 \cdot 3\end{array}$ & $\begin{array}{l}7 \cdot 29 \\
5 \cdot 59\end{array}$ & $\begin{array}{l}.0719 \\
.0531\end{array}$ & $\begin{array}{l}87 \cdot 4 \\
86 \cdot 4\end{array}$ \\
\hline 6 & Rheumatoid Arthritis & $\begin{array}{l}\mathbf{R} \\
\mathbf{L}\end{array}$ & $\begin{array}{l}3 \cdot 7 \\
5 \cdot 5\end{array}$ & $\begin{array}{l}4 \cdot 0 \\
5 \cdot 7\end{array}$ & $\begin{array}{r}7,750 \\
10,600\end{array}$ & $\begin{array}{l}95 \\
95\end{array}$ & $\begin{array}{l}48 \cdot 0 \\
39 \cdot 6\end{array}$ & $\begin{array}{r}12 \cdot 34 \\
5 \cdot 02\end{array}$ & $\begin{array}{l}.0845 \\
.0465\end{array}$ & $\begin{array}{r}134 \cdot 2 \\
86 \cdot 4\end{array}$ \\
\hline
\end{tabular}


ascorbic acid concentrations also had a low reduced viscosity. In those few instances where the synovial fluid ascorbic acid concentration was clearly normal the reduced viscosity was considerably higher than in those fluids with low ascorbic acid concentration. Of interest was Case 2, who on one occasion had synovial fluid from both knees with a low ascorbic acid concentration and a low reduced viscosity, and on another occasion had fluid with both a higher ascorbic acid level and a higher reduced viscosity.

(2) Action of L-ascorbic Acid on Whole Rheumatoid Synovial Fluid in vitro.-L-ascorbic acid in physiological concentration apparently had no viscosity-reducing effect on the hyaluronate present in whole rheumatoid synovial fluid. Table II shows no decrease in the viscosity of rheumatoid synovial fluid. L-ascorbic acid also failed to reduce the viscosity of whole normal synovial fluid. This failure to reduce the viscosity of hyaluronate in synovial fluid was quite unlike the dramatic reduction in viscosity produced by a similar concentration of ascorbic acid on a solution of purified synovial fluid hyaluronate.

(3) Action of L-ascorbic Acid on Whole Rheumatoid Synovial Fluid in vivo.-After intra-articular injection, $100 \mathrm{mg}$. L-ascorbic acid, rapidly disappeared from the knee joint and appeared in the blood. The concentration of ascorbic acid in both the synovial fluid and the serum rose initially and then approached control levels within $3 \mathrm{hrs}$ (Table III). During this time, there was no appreciable change in the reduced viscosity of the synovial fluid (Table III).

(4) Inhibition Studies.-The inhibiting action of various protein solutions on the viscosity reducing effect of L-ascorbic acid on purified hyaluronate was studied (Table IV, overleaf). It was found that undialysed normal serum exhibited the strongest inhibitory action. The alpha $a_{2}$ fraction of both normal serum and rheumatoid synovial fluid exhibited the greatest inhibitory activity of the individual protein fractions. The inhibitory effect of normal serum was only slightly decreased by dialysis.

\section{Discussion}

It was originally shown by Robertson and others (1939) and subsequently studied and confirmed by McClean and Hale $(1940,1941)$, Madinaveitia and Quibell (1941), Skanse and Sundblad (1943), Hale (1944), Robertson and others (1941), Daubenmerkl (1951), and Pigman, Rizvi, and Holley (1961), that L-ascorbic acid could cause a marked decrease in the viscosity of hyaluronate solutions. Little attention has been paid to any role ascorbic acid might have in vivo on the hyaluronate of connective tissue, and, more specifically, to whether the lower viscosity of some rheumatoid synovial fluids might be due to this action of ascorbic acid. Buchan (1951) noted

TABLE II

EFFECT OF ASCORBIC ACID IN VITRO

\begin{tabular}{c|c|c|c|c}
\hline Effect of Ascorbic Acid & Ascorbic Acid $(\gamma / \mathrm{ml})$. & Relative Viscosity & Hyaluronate (g. per cent.) & Reduced Viscosity \\
\hline On Rheumatoid Synovial & 0 & $7 \cdot 61$ & .0718 & $92 \cdot 0$ \\
Fluid & 15 & $8 \cdot 51$ & .0816 & $92 \cdot 0$ \\
\hline On Purified Hyaluronate & 0 & $2 \cdot 26$ & .0210 & $60 \cdot 0$ \\
& 15 & $1 \cdot 08$ & .0188 & $4 \cdot 3$ \\
\hline
\end{tabular}

TABLE III

EFFECT OF ASCORBIC ACID ON THE VISCOSITY OF RHEUMATOID SYNOVIAL FLUID IN VIVO

\begin{tabular}{|c|c|c|c|c|c|c|}
\hline \multirow{2}{*}{ Case No. * } & \multirow{2}{*}{ Time (min.) } & \multicolumn{2}{|c|}{ Ascorbic Acid ( $\gamma / \mathrm{ml}$.) } & \multirow{2}{*}{ Relative Viscosity } & \multirow{2}{*}{ Hyaluronate (g. per cent.) } & \multirow{2}{*}{ Reduced Viscosity } \\
\hline & & Synovial Fluid & Serum & & & \\
\hline 2 & $\begin{array}{r}0 \\
10 \\
25 \\
35 \\
45 \\
210\end{array}$ & $\begin{array}{c}2 \cdot 2 \\
206 \cdot 7 \\
\frac{7}{8 \cdot 6}\end{array}$ & $\begin{array}{l}2 \cdot 0 \\
3 \cdot 8 \\
4 \cdot 3 \\
3 \cdot 0 \\
2 \cdot 7 \\
2 \cdot 1\end{array}$ & $\begin{array}{l}12 \cdot 0 \\
\frac{11 \cdot 8}{\bar{T}} \\
10 \cdot 1\end{array}$ & $\begin{array}{l}\cdot \frac{166}{\overline{164}} \\
\frac{\overline{136}}{\cdot 136}\end{array}$ & $\begin{array}{l}66 \cdot 3 \\
6 \overline{5 \cdot 9} \\
\overline{67 \cdot 0}\end{array}$ \\
\hline 5 & $\begin{array}{r}0 \\
15 \\
190\end{array}$ & $\begin{array}{r}2.9 \\
656 \cdot 3 \\
10 \cdot 1\end{array}$ & $\begin{array}{l}2 \cdot 9 \\
9 \cdot 1 \\
2 \cdot 7\end{array}$ & $\begin{array}{l}8 \cdot 7 \\
8 \cdot 3 \\
9 \cdot 5\end{array}$ & $\begin{array}{l}.093 \\
.088 \\
.090\end{array}$ & $\begin{array}{l}82 \cdot 8 \\
83 \cdot 0 \\
94 \cdot 4\end{array}$ \\
\hline
\end{tabular}

* Case Nos as in Table I. 
TABLE IV

ACTIVITY OF ASCORBIC ACID (15 $\gamma / \mathrm{ml}$.) ON PURIFIED HYALURONATE IN THE PRESENCE OF FRACTIONS OF SERUM OR SYNOVIAL FLUID

\begin{tabular}{|c|c|c|c|c|c|c|c|c|}
\hline \multicolumn{8}{|c|}{ Fraction Added } & \multirow{2}{*}{$\frac{\text { Per Cent. Initial Reduced Viscosity }}{13 \cdot 9}$} \\
\hline \multicolumn{8}{|c|}{ None } & \\
\hline Normal Serum & & $\begin{array}{l}\text { albumir } \\
\text { alpha } 8 \\
\text { alpha } 8 \\
\text { beta glo } \\
\text { gamma }\end{array}$ & $\begin{array}{l}\text { oulin } \\
\text { oulin } \\
\text { lin } \\
\text { bulin }\end{array}$ & $\begin{array}{l}\cdots \\
\cdots \\
\cdots \\
\cdots\end{array}$ & $\begin{array}{l}\cdots \\
\cdots \\
\cdots \\
\cdots\end{array}$ & $\begin{array}{l}\ldots \\
\ldots \\
\cdots \\
\cdots\end{array}$ & $\begin{array}{l}\cdots \\
\cdots \\
\cdots \\
\cdots\end{array}$ & $\begin{array}{l}17 \cdot 4 \\
18 \cdot 1 \\
68 \cdot 5 \\
47 \cdot 7 \\
15 \cdot 2\end{array}$ \\
\hline Rheumatoid Synovial Fluid & & $\begin{array}{l}\text { albumir } \\
\text { alpha } \\
\text { alpha } \\
\text { beta glo } \\
\text { gamma } \\
\text { All frac }\end{array}$ & $\begin{array}{l}\text { oulin } \\
\text { sulin } \\
\text { lin } \\
\text { bulin } \\
\text { as poole }\end{array}$ & $\begin{array}{l}\ldots \\
\cdots \\
\cdots \\
\text { ed }\end{array}$ & $\begin{array}{l}\ldots \\
\ldots \\
\ldots \\
\ldots \\
\ldots\end{array}$ & $\begin{array}{l}\ldots \\
\cdots \\
\cdots \\
\cdots \\
\cdots\end{array}$ & $\begin{array}{l}\ldots \\
\ldots \\
\cdots \\
\cdots \\
\cdots\end{array}$ & $\begin{array}{l}48 \cdot 2 \\
37 \cdot 0 \\
64 \cdot 4 \\
36 \cdot 7 \\
21 \cdot 5 \\
78 \cdot 8\end{array}$ \\
\hline $\begin{array}{l}\text { Ultrafiltrate of Normal Serum } \\
\text { Undialysed Normal Serum } \\
\text { Dialysed Normal Serum } \\
\text { Dialysed Normal Serum + Ult }\end{array}$ & $\begin{array}{r}\cdots \\
\cdots \\
\text { trate }\end{array}$ & $\begin{array}{l}\cdots \\
\cdots \\
\cdots\end{array}$ & $\begin{array}{l}\cdots \\
\cdots \\
\cdots\end{array}$ & $\begin{array}{l}\cdots \\
\cdots \\
\cdots\end{array}$ & $\begin{array}{l}\cdots \\
\cdots \\
\cdots\end{array}$ & $\begin{array}{l}\cdots \\
\cdots \\
\cdots\end{array}$ & $\begin{array}{l}\cdots \\
\cdots \\
\cdots\end{array}$ & $\begin{array}{l}21 \cdot 6 \\
96 \cdot 1 \\
80 \cdot 0 \\
82 \cdot 9\end{array}$ \\
\hline
\end{tabular}

that "in cases of rheumatoid arthritis . . . in which the joint fluid had been examined, a significant relationship was found to exist between the relative viscosity .... and the synovial fluid ascorbic acid levels ... the higher the ascorbic acid, the lower the viscosity".

The ascorbic acid levels in serum and synovial fluid of patients with rheumatoid arthritis were determined. It was noted that in almost all cases the levels of ascorbic acid in serum and synovial fluid were approximately the same. These levels are rather low when compared to the normal values for serum ascorbic acid concentrations, i.e. 2-15 $\gamma /$ $\mathrm{ml}$. Similar low levels $(1 \cdot 4-6 \cdot 6 \gamma / \mathrm{ml}$.) were reported over 25 years ago in the serum of patients with rheumatoid arthritis by Rinehart, Greenberg, and Baker (1936).

The ascorbic acid concentration in synovial fluid was plotted against the reduced viscosity of the fluids. It was noted that those fluids with low ascorbic acid concentrations also had a low reduced viscosity, and in those few instances where the synovial fluid ascorbic acid concentration was clearly normal, the reduced viscosity was considerably higher. These results do not confirm Buchan's findings. The data indicate that the synovial fluid ascorbic acid concentration and reduced viscosity are not inversely proportional.

To clarify these observations, studies were undertaken to determine if $\mathrm{L}$-ascorbic acid could reduce the viscosity of hyaluronate in rheumatoid synovial fluid. Whereas incubation of purified hyaluronate solutions with as little as $15 \gamma / \mathrm{ml}$. L-ascorbic acid produced a striking reduction in viscosity, whole synovial fluid lost none of its viscosity when incubated with this same concentration of ascorbic acid.
Clearly, L-ascorbic acid in physiological concentration does not appear to have an effect in vitro on rheumatoid synovial fluid. Nor does it appear to have any effect in vivo on the hyaluronate in rheumatoid synovial fluid. When $100 \mathrm{mg}$. L-ascorbic acid was injected intra-articularly into the involved knee joint of a patient with rheumatoid arthritis, no change in the reduced viscosity of the synovial fluid was noted. The ascorbic acid, after attaining very high initial levels, was rapidly removed from the knee joint and appeared in the blood. This rapid removal of ascorbic acid from the joint suggests that any ascorbic acid liberated into inflammatory synovial fluid by cells (i.e. leucocytes) would be quickly eliminated; this probably explains the similarity of serum and synovial fluid ascorbic acid levels.

Apparently L-ascorbic acid cannot reduce the viscosity of the hyaluronate in rheumatoid synovial fluid. The inhibition studies presented in this paper show that the proteins of rheumatoid synovial fluid and normal serum can inhibit the effect of L-ascorbic acid on purified hyaluronate. Whole serum inhibited the effect of ascorbic acid to the greatest extent, and the alpha ${ }_{2}$ globulin fractions exhibited more inhibitory activity than any other single fraction. There is as yet no apparent explanation for the different inhibitory activities of the protein fractions of both normal serum and rheumatoid synovial fluid. The inhibitory effect does not apparently parallel the protein concentrations of the

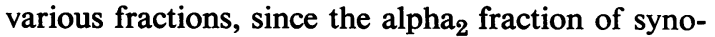
vial fluid contained considerably less protein $(1 \cdot 4$ $\mathrm{mg} . / \mathrm{ml}$.) than either albumin $(5.7 \mathrm{mg} . / \mathrm{ml}$.) or gamma globulin $(3.9 \mathrm{mg} . / \mathrm{ml}$.). Fractions of human serum have been noted before by Salegui, Rizvi, Holley, and Pigman (1962) and Pigman and Rizvi (1959) to 
protect hyaluronic acid from the viscosity-reducing effect of L-ascorbic acid.

These studies by no means exclude the possibility that ascorbic acid may depolymerize hyaluronate in vivo. They do indicate, however, that if ascorbic acid plays a significant role in the degradation of hyaluronate in rheumatoid arthritis, the site of this action is not in the synovial fluid itself. It is possible that ascorbic acid might alter hyaluronate at sites where there may be less inhibitory activity than in synovial fluid. It is conceivable, for instance, that this action of ascorbic acid could occur in the synovial membrane, or perhaps even intracellularly.

\section{Summary}

(1) The serum and synovial fluid ascorbic acid concentrations were compared in patients with rheumatoid synovitis and were shown to be approximately the same.

(2) $\mathrm{L}$-ascorbic acid was shown to have a viscosityreducing effect on solutions of purified hyaluronate but to have no viscosity-reducing effect on whole rheumatoid synovial fluid either in vivo or in vitro.

(3) Inhibition studies indicated that the viscosityreducing effect of L-ascorbic acid on hyaluronate solutions could be inhibited by the proteins present in either normal serum or rheumatoid synovial fluid.

\section{REFERENCES}

Bowness, J. M. (1957). Biochem. J., 67, 295.

Buchan, J. F. (1951). Ann. rheum. Dis., 10, 190 (Discussion).

Daubenmerkl, W. (1951). Acta pharm. toxicol., 7, 153.

Decker, B., McGuckin, W. F., McKenzie, B. F., and Slocumb, C. H. (1959). Clin. Chem., 5, 465.

Dische, Z. (1947). J. biol. Chem., 167, 189.

Hale, C. W. (1944). Biochem.J., 38, 362.

Kunkel, H. G., and Trautman, R. (1959). In "Electrophoresis", ed. M. Bier, vol. 1, p. 225. Academic Press, New York.

Lowry, O. H., Rosebrough, N. J., Farr, A. L., and Randall, R. J. (1951). J. biol. Chem., 193, 265.

Madinaveitia, J., and Quibell, T. H. H. (1941). Biochem. $J ., 35,453$.

McClean, D., and Hale, C. W. (1940). Nature (Lond.), $145,867$.
(1941). Biochem.J., 35, 159.

Pigman, W., and Rizvi, S. (1959). Biochem. Biophys. Res. Comm., 1, 39.

$4,240$.

Rinehart, J. F., Greenberg, L. D., and Baker, F. (1936). Proc. Soc. exp. Biol. (N. Y.), 35, 347.

Robertson, W. V. B., Ropes, M. W., and Bauer, W. (1939). Amer. J. Physiol., 126, 609. (1941). Biochem.J., 35, 903.

Roe, J. H. (1961). J. biol. Chem., 236, 1611.

- and Kuether, C. A. (1943). Ibid., 147, 399.

Ropes, M. W., Bennett, G. A., Cobb, S., Jacox, R., and Jessar, R. A. (1959). Ann. rheum. Dis., 18, 49.

Salegui, M. de, Rizvi, S., Holley, H. L., and Pigman, W. (1962). Fed. Proc., 21, 171.

Sandson, J., and Hamerman, D. (1962). J. clin. Invest., $41,1817$.

Skanse, B., and Sundblad, L. (1943). Acta physiol. scand., 6, 37.

\section{L'effet de l'acide ascorbique sur le liquide synovial rhumatoide}

\section{RÉSUMÉ}

(1) On compara les taux d'acide ascorbique dans le liquide synovial et dans le sérum des malades atteints de synovite rhumatoïde et on les trouva à peu près égaux.

(2) On démontra que l'acide $L$-ascorbique réduit la viscosité des solutions d'hyaluronate purifié mais qu'il n'exerce pas cet effet sur le liquide synovial rhumatoïde entier, ni in vivo ni in vitro.

(3) L'étude de l'inhibition indique que l'effet réducteur de l'acide L-ascorbique sur la viscosité des solutions d'hyaluronate peut être inhibé par les protéines présentes dans le sérum normal ou bien dans le liquide synovial rhumatoïde.

\section{El efecto del ácido ascórbico sobre el líquido sinovial reumatoide}

\section{SUMARIO}

(1) Las cifras de ácido ascórbico en el líquido sinovial y en el suero de enfermos con sinovitis reumatoide fueron comparadas y encontradas aproximadamente iguales.

(2) Se demuestra que el ácido L-ascórbico reduce la viscosidad de soluciones de hialuronato purificado peró no ejerce este efecto sobre el líquido sinovial reumatoide integro, ni in vivo, ni in vitro.

(3) Experimentos de inhibición indican que el efecto reductor del ácido L-ascórbico sobre la viscosidad de las soluciones de hialuronato puede ser inhibido por las proteinas presentes tanto en el suero normal, como en el liquido sinovial reumatoide. 